\title{
An Analysis of Diplomatic Discourse about COVID-19 Based on Engagement System: Taking Foreign Ministry Spokesperson Geng Shuang's Discourse as an Example
}

\author{
Huafeng Wang \\ Faculty of English Language and Culture, Guangdong University of Foreign Studies \\ * E-mail of the corresponding author:20200110064@gdufs.edu.cn
}

\begin{abstract}
With the background of deficient studies on Foreign Ministry spokesperson's discourse from an engagement system and certain spokesperson's characteristics, this paper applies the theoretical framework of engagement system to analyze diplomatic discourse by spokesperson Geng Shuang on regular press conferences. The current study aims to investigate how Foreign Ministry spokesperson technically and politely employed engagement resources to contract and expand dialogic space for preserving Chinese image and minimizing the provocation on COVID-19. Through small-scale quantitative and qualitative methods, it is concluded that the distribution of dialogic contraction resources is more than expanded ones and a great range of "deontic" modality has been employed in dialogic expansion.
\end{abstract}

Keywords: engagement system; diplomatic discourse; dialogic space

DOI: $10.7176 /$ JLLL/78-06

Publication date: April $30^{\text {th }} 2021$

\section{Background}

At the beginning of 2020, COVID-19 spread rapidly around China and the whole world. All civilization has attributed to advance anti-epidemic international cooperation. Chinese Ministry of Foreign Affairs, as the voice of China, firmly and authoritatively sticks to represent an open, peaceful and intelligent government, delivering Chinese stance and attitudes about the current situation of COVID-19 to the public. Discourse is a kind of social practice that reflects social value and social relations. Diplomatic discourse is an important means for the world to comprehend a country's foreign policies on the one hand, and it is also an interface to transmit a country's position or propositions, convey its willingness and handle international affairs during international interaction. Positive and effective diplomatic discourse is conducive to maintaining the image of China as a peaceful and responsible diplomatic power and competing for more international discourse power. The relationship between the spokesperson and reporters is slightly delicate, and each Foreign Ministry's wisdom is reflected in his diplomatic discourse as well, it is vital to explore some certain characteristics beyond discourse.

Although there are many studies about COVID-19 in medical and biological field, it seems that discourse analysis of COVID-19 is still deficient. Therefore, the current study is to analyze diplomatic discourse about COVID-19 from an engagement system, taking Foreign Ministry spokesperson Geng Shuang's discourse as an example.

\section{Literature Review}

\subsection{Appraisal System}

\subsubsection{The Introduction of Appraisal System}

Based on Halliday's Systemic-Functional Grammar (1973), language is realized through three meanings: interpersonal meaning, ideational meaning and textual meaning. Each meaning corresponds to one kind of metafunction. Specifically, the key presentations of interpersonal meta-function are mood and modality system. Transitivity system is the most significant part in ideational meta-function, including six types of process: material process, relational process, mental process, behavior process, verbal process and existential process, while textual meta-function is realized through thematic structure and cohesion (Halliday 2000).

Appraisal system, regarded as a new development and orientation in ideational meaning of systemic functional linguistics, concentrates on semantic of evaluation. Martin (2003) defined that, appraisal theory is about all 
attitudes, all intensity of mood and all means to reflect appraisal in discourse when negotiating with others. According to Martin (2000), appraisal system contains three sub-systems: engagement, attitude and graduation. To be more specific, attitude system refers to judegment and appreciation to behavior, text and phenomena after influencing the language users' mentality (Wang 2001). Through comparison of various engaged tools, engagement system can be divided into monogloss and heterogloss. And graduation presents grading phenomena whereby feelings are amplified and categories blurred (Martin \& White 2005). The current study is to discuss from the perspective of engagement system in detail.

\subsubsection{Engagement System}

Engagement refers that the speaker chooses different devices to engage or mediate discourse, which emphasizes various negotiated means to realize ideational meaning. On the basis of White's definition (2003), engagement is the way that text is used to negotiate meanings with actual and potential audience. The language user adjusts his or her orientation to his responsibility and obligation to speak or write through engagement. Projection, hedging and modality are used to measure whether the language user "engages" the responsibility or not (Wang 2001).

Engagement system is to analyze original sources of attitude, which contains two sub-systems: monogloss and heterogloss. Monogloss refers that the speaker's own narration or argumentation without any other interrupt or disturbance. Therefore, the proposition's statement is the major overt form of monogloss. Besides, due to the characteristic of monotony, the speaker should be responsible for his statement or judgement. In terms of heterogloss, White (2003) proposed that alternative voices and stance are permitted within the same textual, which represents the communicative context as one of heteroglossic diversity. Heterogloss accepts the existence of multiple voices and diverse engagement resources: one language user has chosen his way to state his standpoint while others are using their preference to negotiation. Considering the degree of dialogic openness, heteroglossic has two representations: dialogic contraction and dialogic expansion. Dialogic contraction means challenging and even restricting alternative standpoints as other speakers engage in, primarily divided into disclaim and proclaim. In contrary, dialogic expansion warmly receives distinctive discourse and provides enough space for others to communication, including entertain and attribute. The current study will only concentrate on the analysis of heterogloss.

\subsection{Diplomatic Discourse}

As an indispensable part in political arena, diplomatic discourse is always formalized into special patterns and has been designed to oil the joints of relationship between people and nations (Jaber 2001). It is a special language from diplomats to minimize the provocation caused by a sharp or threatening information (Berridge \& James 2001:67). The regular press conference of the Foreign Ministry is not only a bridge to elaborate Chinese stance or attitudes and advance international communication and cooperation, but also a platform to release the newest message on Chinese crucial diplomatic activities and foreign policy for the Chinese public.

In the light of the uniqueness of Foreign Ministry spokesperson's discourse, many researchers have explored it from various perspectives. Ning Yan (2010), from the view of words and sentence patterns, summarized that scope vagueness words and extent vagueness words were two distinct manners to realize pragmatic vagueness in news release conference of Chinese ministry of foreign affairs. Based on the analysis of Xiao Danqing (2014), spokesperson would adopt diverse strategies when answering diverse sorts of semantic types of questions. Through systematic analysis of data, Zuo Kemin (2016) confirmed that attitude system was the most frequently used system in official discourse. Yang Yiqi (2020), focusing on attitude system, proved that spokesperson carefully and wisely selected words for judgement, afftect and appreciation. Moreover, it is concluded that the frequency of using dialogic expansion was more than dialogic contraction and diplomats tried to provide a more open space and establish solidarity with the reporter (Lai Ping 2012).

However, the majority researchers mainly rationales diplomatic discourse in consideration of pragmatics, such as pragmatic vagueness, responsive discourse strategies and pragmatic presupposition (Ning Yan 2010; Zhang Li 2013; Zhang Li 2014; Zhao \& Zhan 2018; Zhang \& Liu 2019; Zhao Yu 2019; Hou Lusha 2017; Lü Jia 2014). Although there are several studies on diplomatic discourse through the theoretical framework of appraisal system, it seems that the analysis of Foreign Ministry spokesperson's discourse from an engagement system is deficient. Furthermore, previous studies solely emphasized the general characteristics of Foreign Ministry spokesperson's discourse; it appears that studies on certain spokesperson's discourse are not sufficient. For these reasons, the current study has adopted small-scale quantitative and qualitative methods to find out and reveal how Geng Shuang technically and politely applied engagement system to contract and expand dialogic space for preserving Chinese image and minimizing the provocation on COVID-19. 


\section{Data Collection and Analysis}

\subsection{Data Collection}

April, 2020 was the turning point that only China has been recovering from the epidemic peacefully and successfully around the world, while the COVID-19 situation outside China was still negative and even severe. It is the time when all other countries have tried to imitate Chinese triumphant resistance measures to the epidemic. Meanwhile, China has also attributed to cooperate with international community, supporting underdevelopment and several European developed countries as possible as she can. Besides, these selected regular press conferences were the last stage of Geng Shuang as a Foreign Ministry spokesperson. The corpus of this time span, of course, is very representative for dealing with international affairs and meaningful to explore his diplomatic wisdom.

All data was collected from English version of Foreign Ministry spokesperson Geng Shuang's regular press conference from April 20, 2020 to April 30, 2020 and downloaded these 9 texts from the Ministry of Foreign Affairs of the People's Republic of China. The material merely contains Geng Shuang's answers to the reporters at home and abroad. The debating point seems highly consistent in these materials: Some American and Australian politicians attempted to investigate origins of the COVID-19 in China, doubted it was engineered in the Wuhan's lab and argued that China should be blame for a "crime" that they didn't put information out into the international space as they were required to do in a timely fashion. Having sorted out carefully, there are 17 , 383 tokens in total, which has been input in AntConc 13.3 (Windows) and has built a small corpus for conducting quantitative analysis. Then useful data has been extracted in accordance with the theoretical framework of engagement system. Conversely, qualitative analysis was conducted by analyzing certain typical examples based on the distribution of engagement resources.

\subsection{Data Analysis}

\subsubsection{Quantitative analysis}

Statistics show that there are 481 tokens of engagement resources among these 9 materials from the Foreign Ministry spokesperson Geng Shuang's regular press conference, including 256 (53.22\%) tokens of dialogic contraction and $225(46.78 \%)$ tokens of dialogic expansion. The following two tables are the detailed information.

According to table 1 (Distribution of dialogic contraction), "disclaim" resources (198) are apparently more than "proclaim" resources (58) on the whole, which indicates that there are some disagreement or contrary discourse between Geng Shuang and the reporters. To be more specific, "deny (115)" , accounting for 58.08\% of all "disclaim" resources, is a little more than "counter (83)", which only accounts for $41.92 \%$. Meanwhile, the word "not (55)" is the most frequently used and the words "didn't (1)", "reject (1)" seem infrequent when denying others. While Geng Shuang tends to choose the words "only (22)" and "but (22)" for countering. Generally speaking, the distribution of "proclaim" resources is relatively uneven, where there are 3 tokens for "concur", taking up 5.17\% of all "proclaim" resources; 29 tokens for "pronounce", occupying 50\% and 26 tokens for "endorse", accounting for $36.76 \%$. We can summarize that "pronounce" is the main device to "proclaim".

With a view to table 2 (distribution of dialogic expansion), it is prominently manifested that Geng Shuang is inclined to "entertain" resources than "attribute" resources, where "entertain" resources have 161 tokens, taking up $71.56 \%$ and "attribute" resources merely have 64 tokens, occupying $28.44 \%$. More specifically, the using of modal auxiliary verbs, such as "may, will, must, could" (131) accounts the vast majority in reporting other discourse. Apart from these, the number of "acknowledge" (64) is 6 times than "distance" (11) within "attribute" resources.

From the data, we could infer that Geng Shuang has a little preference to dialogic contraction than dialogic expansion in general, which means that Geng Shuang resists some injudicious remarks or irrational questions when some reporters have distorted certain facts. Therefore, it is concluded that Geng Shuang permits a narrow space for reporters to questioning or communicating. More specific and typical examples of Geng Shuang's discourse will be presented in the following part. 
Table 1: Distribution of dialogic contraction

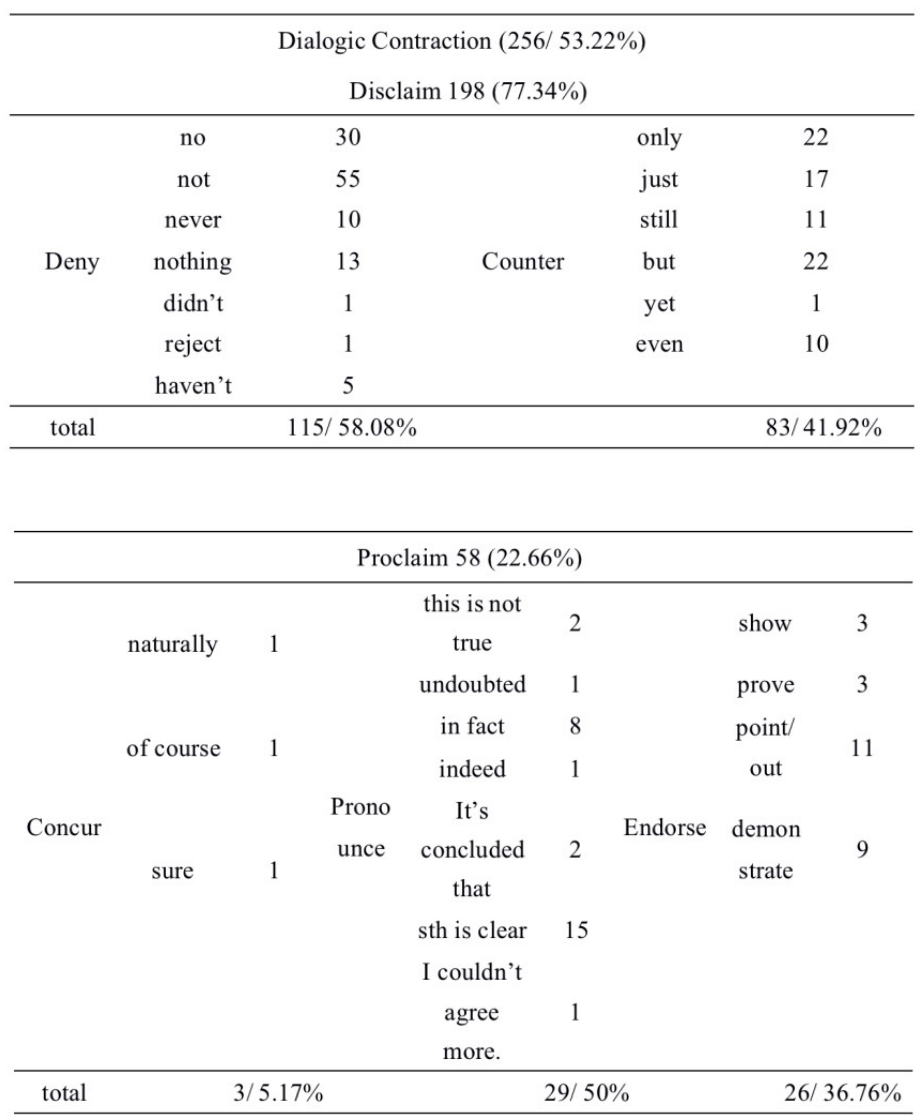


Table 2: Distribution of dialogic expansion

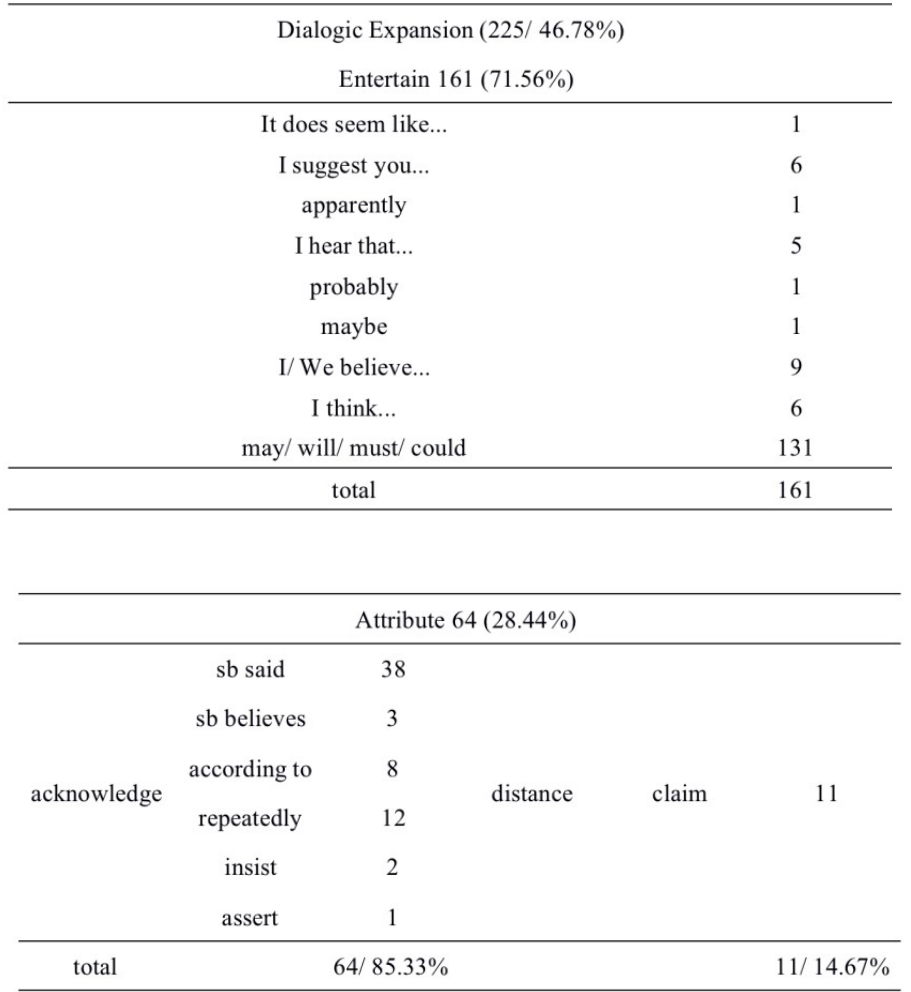

\subsubsection{Qualitative analysis}

\subsubsection{Dialogic contraction}

Disclaim refers that the speaker directly rejected, replaced or held to be unsustainable when facing some prior utterance or some alternative position (Martin \& White 2005:117). "Deny" is directed and away from the current speak- audience relationship (Martin \& White 2005:118). As the above statistic has shown, the word "not" is the most frequently used in "deny", which has 55 tokens, occupying merely half of "deny" resources. For example,

(1) The virus is a common enemy to all mankind and may strike anytime, anywhere. Like other countries, China is also a victim, not (deny) a perpetrator, even less an accomplice of COVID-19. (2020-04-20)

(2)Australian Foreign Minister Payne's remarks are not (deny) based on facts. China is seriously concerned about and firmly opposed to this. (2020-04-20)

When it comes to distorting the fact that China should be 'knowingly responsible' and be investigated the origin of COVID-19 by US president Trump and Australian Foreign Minister Payne, Geng Shuang resolutely resisted such statements and claimed these were not based on facts. Meanwhile, he emphasized that the international community should stand in solidarity and work together, rather than resorting mutual accusation or demand retribution and accountability. He employed direct denial to contract the degree of dialogic openness, treating as a challenge instead of a soften suggestion for the audience. Having felt such reminder, the reporter unconsciously understood Geng Shuang's position and then reached an agreement that all human beings must keep a more objective, scientific and scrupulous attitude towards the civilization-wide disaster as well.

Another new finding which differentiates from previous studies (Wu Hanfan 2020; Zuo Kemin 2016) is that the present perfect tense "haven't" is likewise an effective measure to deny some certain things. The following two examples have testified that spokesperson tried to make the audience acceptable and keep alignment with him through a present perfect tense "haven't".

(3) I wonder how you drew the conclusion of China being not friendly based on the ambassador's remarks. I

${ }^{1}$ All examples cited from regular press conference in this paper have been numbered in italics. 
haven't (deny) heard that from anyone else before. (2020-4-28)

(4)I didn't say I haven't (deny) read it. What I said is I don't know what the source is, and I have nothing to say on the news story. (2020-4-28)

"Counter" means that the speaker uses another unexpected proposition to replace the current one. From the data, "only" and "but" account a grate range of "counter" resources. For example,

(5)The US has been smearing and attacking WHO without any factual basis. Its tactics of pressure and coercion will only (counter) draw greater disapprobation from the international community. (2020-4-24)

(6) The US should also be clear that countries should tide over the difficulties together. Undermining others' endeavors will only (counter) end up damaging its own. (2020-4-30)

(7) I noted reports on that. It's just (counter) all too obvious why some political forces in the US have been obsessively attacking China using the pandemic as a weapon. (2020-4-27)

8Is it because of anything wrong on China's part, or just (counter) because they want to hide or fudge anything?

From our standpoint, China has been advancing international anti-pandemic cooperation in close communication and exchanging messages to share experience to the world. Two evaluative words "only", "just" have implied the spokesperson's stance: US wanted to attack and smear China to deflect attention and shift the blame other than focusing on domestic pandemic. Geng Shuang projected a more expected proposition by means of "counter" resources and helped the reporter to adjust their previous misinterpretation accordingly.

In line with Martin and White (2005:98), "proclaim" stands for a highly warrantable textual voice, which sets itself against, suppresses or rules out alternative positions. "Pronounce" means authorial approval of the current interpretation. From table 1, what is clear that "pronounce" has a large proportion in "proclaim" resources. At the same time, Geng Shuang preferred to use the sentence pattern "sth is clear" to stress the indisputable truth. For example,

(9) One thing is clear (pronounce): In an open, transparent and responsible spirit, China has contained COVID19 at home and made important contribution to the global fight, which is fully recognized and highly commended by the international community. (2020-4-30)

(10I will just stress that the virus knows no borders and this pandemic is the common enemy of mankind. It is pretty clear (pronounce) now that some people are deflecting their responsibility mainly to cover up their own problems. (2020-4-22)

From the above two examples, Geng Shuang not only stressed the truth that China is a committed country and has been making efforts to fight virus through "pronounce" resources, but also highlighted US intentional confusion of the public. As a spokesperson of Chinese government, he declared overt authorial interventions to enhance the authority and authenticity of his stance for one thing, for another, weaken the credibility of other views to reach a consensus between the spokesperson and the reporter.

\subsubsection{Dialogic expansion}

For expansion, statistics have shown that "entertain" resources are extensively more than "attribute" resources in general. "entertain" is concerned with permission and obligation, which is realized by the category of "deontic" modality, such as "may, will, must, could" (Martin \& White 2005:105). On the basis of AntConc 13.3, "may" appears 12 times, "will" 108 times, "must" 6 times and "could" 5 times respectively. For example,

(11)Here's my advice: First, you may (entertain) ask the competent authorities; second, you may (entertain) stay patient for a little bit longer and the arrangements will be made public in due course. (2020-4-29)

(12)China will (entertain) continue standing firmly with the international community to defeat the pandemic. We will (entertain) continue helping other countries as much as we can. Like I announced earlier, there will (entertain) be video conferences between China and African countries. We will (entertain) also offer greater, more concrete support to them. (2020-4-27)

13)First I must (entertain) stress that China stands against the creation and spread of disinformation by any individual or institution. (2020-4-27)

(14)I must (entertain) stress again that the sole purpose for some US politicians trying to fool others with their obvious lies is to shift the blame of their own incompetence. (2020-4-28)

(5) I suggest you get a deeper understanding of China and I'm afraid you may have some biases to overcome in this process. We could (entertain) have more discussions on this issue someday if necessary. (2020-4-28) 
(6)Is there any problem with that? How could (entertain) it have anything to do with "economic coercion"?

From the above examples, "will" was more frequently than other modal auxiliary verbs, manifesting that spokesperson expressed his position in a moderate manner rather than a direct rejection. On the other hand, these promises were regarded as good examples in the world, creating the image a responsible great power. "must" was the strongest mood, however, indicating that there was the least space for negotiation concerning contorting China as a victim to a source of disinformation. While the use of "may" and "could" showed that Geng Shuang gave some suggestions for the audience out of diplomatic courtesy rather than a command in order to maintain mutual relationship. With the help of diverse "entertain" resources, the spokesperson has achieved an aligned relationship with the audience.

"attribute" refers to the possibility of alternative propositions when the speaker delivers internal authorial meaning through external sources. "attribute" is made up of "acknowledge" and "distance". "acknowledge" is neutral in "attribute" resources, mainly realized through the sentence pattern "sb. said" accordingly. Conversely, "distance" means to present the authorial proposition without taking responsibility for it, typically depended on “claim". For example,

(7) Like I said (acknowledge) yesterday, Navarro is a habitual liar. Now even his own people find him impossible to listen to. (2020-4-29)

(8) Like we said (acknowledge) repeatedly, tracing the origin of the virus is a scientific matter, which should be studied by scientific professionals. (2020-4-28)

(9I'd like to stress again that Australia's claim (distance) of China's “economic coercion" is simply baseless. As the world economy faces the impact of COVID-19, China would like to cooperate with all countries, help each other, tide over the difficulties together, and contribute to the health and well-being of the entire human race. (2020-4-29)

(0)Therefore there is no reason justifying the claim (distance) that China has taken the most comprehensive, rigorous and thorough measures to contain its spread and conduct international cooperation. (2020-4-20)

With regards to judge Navarro's discourse, Geng Shuang principally has used the first person, such as "I, we", leaving more space for receiving other points of view. As for "claim", the spokesperson distanced himself from such discourse, actually, he was in an opposite position. Therefore, we could infer that "distance" is a kind of implicit negation to the audience.

\section{Major Findings and Conclusion}

With detailed quantitative and qualitative analysis of 9 materials from Geng Shuang's regular press conferences, engagement system has played an significant part in delivering the spokesperson's stance. Several characteristics of Geng Shuang's discourse as a spokesperson of China has been reveled. First and foremost, with respect to some COVID-19 facts of China, the distribution of dialogic contraction resources is more than expanded ones. Specifically, more frequent measure "deny" is used to express an opposite position and contract the current dialogic space. Secondly, a great range of "deontic" modality has been employed in dialogic expansion, which opens up more space for other viewpoints and implies that there are might some possibilities for certain prepositions. To sum up, this diplomatic discourse has indicated Geng Shuang's diplomatic wisdom to maintain an open, transparent and responsible image of China and minimized the provocation on COVID-19.

However, the current study has two limitations: the corpus of Geng Shuang's discourse is too small and it solely contains one aspect of appraisal system. Taking these two aspects into consideration, further study will be conducted to build a much larger corpus of diplomatic spokesperson's discourse and analyzed it from a more comprehensive perspective through mutual comparison.

\section{References}

G. R. Berridge. \& Alan, James. (2001). Dictionary of Diplomacy (2nd edn.). Basingstoke: Palgrave MacMillan.

Halliday, M. A. K. (1973). Language in a Social Perspective: Explorations in the Functions of Language. London: Edward Arnold.

Halliday, M. A. K. (2000). An Introduction to Functional Grammar. Beijing: Foreign Language Teaching and Research Press.

Hou, Lusha. (2017). Waijiaobu fayanren yingda huayu zhong de lunbian celüe: yi gengshuang jiu renquan wenti 
dajizhewen weili (Argumentative strategies in Foreign Ministry spokespersons' replies at the press conference: Taking Geng Shuang's reply about the human rights issues as case study). Kaoshi $y u$ pingjia (Daxue yingyu jiaoyanban) (College English Teaching \& Research) 4, 111-114

Jaber, K. S. (2001). Language and Diplomacy. Retrieved from http://www. Diplomacy. edu/ Books/language and diplomacy /book. htm

Lai, Ping. (2012). Engagement Resources in Diplomatic Discourse: With Reference to Remarks by Chinese Foreign Minister Yang Jiechi at Press Conferences. [MA], Fujian Normal University.

Lü, Jia. (2014). Yuyongyushe zai xinwenfayanren yingdahuayu zhong de gongneng tanxi: yi waijiaobu xinwen fabuhui huayu weili (The function study on pragmatic presupposition in spokesman's speech: Taking speeches in press conference of China's Foreign Affairs Ministry as examples). Shijiazhuang tiedao daxue xuebao (shehui kexue ban) (Journal of Shijiazhuang Tiedao University(Social Science Edition)) 2, 37-40, 64

Martin, J. R. (2000). Beyond exchange: Appraisal system in English. S. Hunston and G. Thompson (eds.), Evolution in text: Authorial stance and construction of discourse. Oxford: Oxford University Press.

Martin, J. R. \& Rose, David. (2003). Working with Discourse. London \& New York: Continuum.

Martin, J. R. \& White, P. R. R. (2005). The Language of Evaluation: Appraisal in English. Beijing: Foreign Language Teaching and Research Press.

Ning, Yan. (2010). A Research about Pragmatic Vagueness in News Release Conference of Chinese Ministry of Foreign Affairs. [MA], Jinan University.

Wang, Zhenhua. (2001). Pingjia xitong jiqi yunzuo: xitong gongneng yuyanxue de xinfazhan (Appraisal systems and their operation: A new development in the systemic functional linguistics.) Waiguoyu (Shanghai waiguoyu daxue xuebao) (Journal of Foreign Languages) 6, 13-20

$\mathrm{Wu}$, Hanfan. (2020). Engagement resources in diplomatic discourse: With reference to remarks by Chinese Foreign Ministry spokesperson. US-China Foreign Language.

Xiao, Danqing. (2014). A Research on the Question and Answer in the Foreign Ministry's Regular Press Conference. [MA], Jiangxi Normal University.

Yang, Yiqi. (2020). Waijiao huayu de taiduxitong yanjiu: yi waijiaobu fayanren dajizhewen zhongshemei shiwu weili (A systematic study on the attitude of diplomatic discourse: A case study of a foreign ministry spokesperson's answer to a reporter's question on US-related affairs). Guoji gongguan (PR Magazine) 2 , 266-267, 269

Zhang, Chen. (2019). Zhongguo waijiaobu fayanren zai lixing jizhehui shang dajizhewen de mohuxianzhiyu yanjiu (A spokesman for China's Foreign Ministry responded to reporters' questions at a regular press briefing on vague language restrictions). Haiwai yingyu (Overseas English) 18, 79-80, 87

Zhang, Li. (2013). Study on the Fuzzy Phenomena of Language in the Foreign Ministry News Conference Answering Reporters' Questions. [MA], Shandong University.

Zhang, Li. (2014). The Implied Meaning of the Diplomatic Fuzzy Language Research. [MA], Central China Normal University.

Zhao, Jing. \& Zhan, Quanwang. (2018). Zhongmei waijiaobu fayanren zai lixing jizhehui shang shiyong mohuxianzhiyu de duibi fenxi (A comparative study of hedges used by Chinese and American Foreign Ministry spokesman in regular press conference). Fuyang shifan daxue xuebao (shehui kexueban) (Journal of Fuyang Normal University (Social Science Edition)) 3, 43-49

Zhao, Yu. (2019). A Study on the Pragmatic Paradigm of Response Discourse and Its Pragmatic Value of Foreign Ministry Spokespersons. [MA], Guangxi Normal University.

Zuo, Kemin. (2016). An Analysis of Official Discourse about the Dispute of South China Sea from the Perspective of Appraisal Theory. [MA], Jinan University. 